\title{
Differential allelopathy between genders of an invasive dioecious tree on desert plants
}

\author{
Marcela Avendaño-González ${ }^{1}$, Ernesto I. Badano ${ }^{1,3}$, Jorge E. Ramírez- \\ Albores ${ }^{1}$, Joel Flores ${ }^{1}$, Jorge A. Flores-Cano ${ }^{2}$
}

Botanical Sciences

94 (2): 253-262, 2016

DOI: $10.17129 /$ botsci.522

\section{Abstract}

The Peruvian peppertree (Schinus molle) is a dioecious species from South America that was introduced into central Mexico five centuries ago. This tree has invaded abandoned agricultural fields from semiarid regions, where it can be found with several native succulent plants that have recolonized these areas. Although peppertrees have negative allelopathic effects on crops, their effects on these native plants remain unknown. Indeed, the allelopathy of peppertrees has only been tested for female individuals, while the allelopathic potential of male peppertrees has not been assessed yet. This study focused on these issues and assessed whether peppertrees affect germination of succulent plants from the Chihuahuan Desert and whether these effects differ between male and female trees. For this we conducted a series of germination bioassays where seeds of native species were watered with aqueous extracts of staminate flowers and leaves produced by male peppertrees, and with aqueous extracts of fruits and leaves produced by female peppertrees. Additionally, we conducted experiments where seeds of native species were sowed on soils collected beneath the canopy of both tree genders. The results of all these experiments indicated that both peppertree genders can reduce germination of native species, but also suggested that male peppertrees would have stronger allelopathic effects than female peppertrees. To our best knowledge, this is the first study reporting allelopathic effects of peppertrees on native plants from Mexico, but this is also the first study indicating differential gender effects for invasive dioecious species with allelopathic potential.

Keywords: abandoned fields, cacti, interference, Peruvian peppertree, semiarid ecosystems, vegetation recovery

\section{Alelopatía diferencial entre los géneros de un árbol invasor dioico sobre plantas de desierto \\ Resumen}

El pirul (Schinus molle) es una especie dioica de Sudamérica que fue introducida en México hace cinco siglos atrás. Este árbol ha invadido campos agrícolas abandonados de regiones semiáridas, donde puede ser encontrado con varias especies de plantas suculentas nativas que han recolonizado estas áreas. Aunque los pirules tienen efectos alelopáticos negativos sobre los cultivos, sus efectos sobre estas plantas nativas siguen siendo desconocidos. De hecho, la alelopatía de los pirules sólo se ha probado para individuos femeninos, mientras que el potencial alelopático de los pirules masculinos aún no se ha evaluado. Este estudio se enfocó en estos estos temas y evaluó si los pirules inhiben la germinación de plantas suculentas del desierto Chihuahuense y si estos efectos difieren entre árboles masculinos y femeninos. Para ello se realizó una serie de bioensayos de germinación donde semillas de las especies nativas fueron regadas con extractos acuosos obtenidos de flores estaminadas y hojas producidas por pirules masculinos, y con extractos acuosos de frutos y hojas producidas por pirules femeninos. Adicionalmente, realizamos experimentos donde semillas de las especies nativas fueron sembraron en suelos recogidos bajo el dosel de ambos géneros de pirul. Los resultados de todos estos experimentos indicaron que ambos géneros del pirul pueden reducir la germinación de especies nativas, pero también sugirieron que los pirules masculinos tendrpian efectos alelopáticos más fuertes sobre las especies nativas que los pirules femeninos. Hasta donde estamos enterados, este es el primer estudio que reporta efectos alelopáticos de los pirules sobre plantas nativas de México, pero esto también es el primer estudio que indica los efectos de diferenciales del género para especies invasoras dioicas con potencial alelopático.

Palabras clave: campos abandonados, cactus, interferencia, Pirul, ecosistemas semiáridos, recuperación de vegetación 
lien plants usually colonize areas affected by human activities where native vegetation has been partially or completely removed (Lozon and MacIsaac, 1997; Alston and Richardson, 2006). After their establishment, these invasive plants can prevent the recovery of native vegetation in several ways (Levine et al., 2002; Didham et al., 2005). Higher competitive ability is a major mechanism by which invasive plants can interfere with the recovery of native communities (Eliason and Allen, 1997; Bakker and Wilson, 2001; Badano and Pugnaire, 2004; Castro et al., 2010). Nevertheless, some invasive species also produce secondary metabolites that can inhibit the germination and growth of other plants in their surroundings (Ridenour and Callaway, 2001; Inderjit et al., 2008; Zhang and Fu, 2009). Although this allelopathic inhibition, as commonly referred to, occurs without involving direct competition among species, allelopathic plants take advantage from this process because they can monopolize the use of resources within their area of influence by excluding other potential competitors (Muller, 1969).

This could be the case of the Peruvian peppertree (Schinus molle L.; Anacardiaceae) in Mexico. This dioecious tree was introduced from South America by the middle of the $16^{\text {th }}$ century as result of the commercial exchange between the former viceroyalties of Peru and New Spain (Kramer, 1957). Peppertrees were quickly incorporated into the Mexican culture because of their rapid growth to obtain raw materials and several ethnobotanical uses in traditional medicine (Bye and Linares, 1983; Paredes-Flores et al., 2007; Blancas et al., 2010). Nevertheless, their prolific seed production (female trees produce above 10,000 seeds per year) allowed them to naturally colonize abandoned agricultural fields form central Mexico (Ramírez-Albores and Badano, 2013). Currently, several native succulent plants are also colonizing these abandoned fields, but they are rarely found beneath the canopy of peppertrees (Ramírez-Albores and Badano, 2013). This suggests that peppertrees could interfere with the establishment of native plants.

Peruvian peppertrees produce several secondary metabolites that have been proven to reduce germination of crops, including flavonoids, oleoresins, tannins, terpenes and saponins (Zahed et al. 2010; Barroso et al., 2011). However, as far as we are aware, these negative effects on crop germination have been only evaluated for fruits and leaves produced by female peppertrees (Anaya and Gomez-Pompa, 1971; Materechera and Hae, 2008; Zahed et al., 2010; Barroso et al., 2011), while the allelopathic potential of male individuals have not received much attention. Therefore, the allelopathic effects of peppertrees on Mexican succulent plants remain unknown, as well as the differential effects that male and female trees may have on these species. In this study we performed a series of laboratory and greenhouse experiments addressed to test these effects. We specifically focused on (1) determining whether Peruvian peppertrees have the potential to reduce the germination and growth succulent plants from the Chihuahuan Desert, and (2) assessing whether male and female individuals of this invasive tree have differential allelopathic effects on these species.

\section{Materials and methods}

Field site description. All plant material used in this study was collected in an abandoned agricultural field invaded by Peruvian peppertrees near the city of San Luis Potosí, central Mexico $\left(22^{\circ} 5^{\prime} \mathrm{N} ; 100^{\circ} 45^{\prime} \mathrm{O} ; 1976-2015 \mathrm{~m}\right)$. Mean annual temperature in this site is $16.9^{\circ} \mathrm{C}$ and precipitation averages $352 \mathrm{~mm}$ per year (Medina-García et al., 2005). Up to $90 \%$ of rainfalls occur between June and October, while a markedly dry season occurs between November and May (Medina-García et al., 2005). The density of adult peppertrees in this site is 28.4 individuals per hectare and the proportion of sexes is almost 1:1. The density of recruiting peppertrees (i.e., non-reproductive individuals) is 5.3 peppertrees per hectare.

Native species seed collection. Six succulent plant species were used to test the allelopathic effects of peppertrees. These species included four endemic cacti [Echinocactus platyacanthus Link \& Otto, Mammillaria longimamma DC., Ferocactus latispinus (Haw.) Britton \& Rose, and Myrtillocactus geometrizans Console] and two succulent monocots of the family Asparagaceae (Agave salmiana Otto ex Salm-Dyck, and Yucca filifera Chabaud). Seeds of all these species were obtained by collecting mature fruits between October 2012 and January 2013. Although all these species are well known to produce fruits with large amounts of viable seeds (50 and 
300 seeds per fruit; Arredondo-Gómez and Sotomayor, 2009), we collected fruits from different parental plants of each species to capture any potential variability in seeds traits (e.g., maternal effects). For this, 10-20 parental plants of each species were randomly selected in the field site and we collected 2-5 fruits on each of them. Fruits were carried to the laboratory and cleaned to release the seeds. The seeds were disinfected with $1 \%$ sodium hypochlorite solution for $1 \mathrm{~min}$, rinsed with distilled water, and air-dried during $24 \mathrm{~h}$. Seeds were later stored in ventilated plastic flasks until their use in the experiments described below.

Allelopathic potential of peppertrees. We firstly performed a series of in vitro germination bioassays addressed to test whether the different peppertrees organs contain secondary metabolites with the potential to prevent germination of native plants, as well as to assess whether these effects differ between male and female trees. In these bioassays, seeds of native species were watered with aqueous extracts obtained from staminate flowers and leaves produced by male individuals, and with aqueous extracts obtained from fruits and leaves produced by female trees. Plant organs of peppertrees were collected in April 2013 (dry season) by randomly selecting ten individuals of each gender in the field site. On male trees we collected $100 \mathrm{~g}$ of mature leaves and $100 \mathrm{~g}$ of staminate flowers, while on female trees we collected $100 \mathrm{~g}$ of mature leaves and $100 \mathrm{~g}$ of mature fruits. Pistillate flowers were not included because most of them had already developed the fruit by the moment in which plant organs were collected. Plant organs were pooled across trees of each gender to obtain a composite sample of $1 \mathrm{~kg}$ per plant organ. These samples were rinsed with distilled water during 1 min to remove dust and any other particulate materials. We did it because contaminants from urban areas neighboring the field site might reach the peppertrees and accumulate on them, which in turn could interfere with the assessment of their allelopathic effects. Thus, although washing may remove some secondary metabolites accumulated on the surface of plant organs, we preferred assessing the allelopathic effects of secondary metabolites contained within plant organs to avoid biased effects of due to the presence of external contaminants. After rinsing, composite samples of plant organs were air-dried during $24 \mathrm{~h}$ under laboratory conditions $\left(20^{\circ} \mathrm{C}\right)$.

Aqueous extracts were prepared within $24 \mathrm{~h}$ after collection of plant organs. For this, $100 \mathrm{~g}$ of each plant organ (staminate flowers, fruits and leaves of male and female trees) were crushed it with $1 \mathrm{~L}$ of distilled water. Resulting blends were collected in sterilized amber flasks and incubated during $48 \mathrm{~h}$ in a refrigerated chamber $\left(5^{\circ} \mathrm{C}\right)$ to prevent degradation of tissues and metabolites due to enzymatic activity, as well as to reduce the potential fermentative activity of microorganisms that may be contained in plant organs. Blends were later filtered and the resulting extracts were used in the germination trials described below. This procedure concurs with those used by other authors that have assessed the allelopathic effects of peppertrees on crops (Materechera and Hae, 2008; Borella et al. 2011). Nevertheless, since the inhibitory effects of allelopathic compounds usually depend upon their concentrations (Batish et al., 2002; Materechera and Hae, 2008), a fraction of the extracts was diluted to the half of its original concentration. Thus, for each plant organ we obtained a concentrated extract equivalent to $100 \mathrm{~g}$ of plant organs per liter of distilled water, and a diluted extract equivalent $50 \mathrm{~g}$ of plant organs per liter of distilled water.

To test the allelopathic effects of these extracts we prepared 270 plastic Petri dishes $(50 \mathrm{~mm}$ diameter by $12 \mathrm{~mm}$ deep) using sterile cotton pads as germination substrate. We assigned 45 of dishes to each native species and sowed 20 seeds of the respective species on these dishes. For each species, these dishes were split into nine groups (5 dishes per group); eight groups of dishes separately received $5 \mathrm{~mL}$ of the different aqueous extracts (male flowers, fruits, and leaves of male and female trees) at the two concentrations (concentrated and diluted extracts), while the ninth group of dishes only received distilled water (control group). Therefore, a total of 100 seeds of each species received each watering treatment. These treatments were only applied at the beginning of the experiment and dishes were sealed with Parafilm ${ }^{\circledast}$ to avoid water loss. Neither water nor additional extracts were added afterwards. These dishes were randomly arranged within a grow chamber $\left(25{ }^{\circ} \mathrm{C}, 60 \%\right.$ relative humidity, photoperiod $12 \mathrm{~h}$ dark/light) and germination within each dish was monitored every two days during 30 days. In all cases, germination was assumed when the emergence of the radicle was observed. 
Allelopathy in soils beneath peppertrees. To assess whether secondary metabolites produced by peppertrees are released to the environment, an also assess whether they retain their capability to inhibit germination of native species, we conducted a greenhouse germination experiment. For this, we randomly selected five trees of each gender in the field site and collected $2 \mathrm{~L}$ of soil (first $10 \mathrm{~cm}$ of the soil profile) beneath their canopies. The same procedure was used to collect control soil in five open areas without vegetation cover, always maintaining a minimum distance of $20 \mathrm{~m}$ from the canopy of any peppertree. Samples belonging to the same soil type (male trees, female trees and control soil) were pooled and meshed to remove leaf litter and other coarse materials.

For each native species, ten plastic pots of $100 \mathrm{ml}$ were filled to $3 / 4$ of their capacity with each of these soil types ( 10 pots $\times 3$ soil types $=30$ pots for each species $)$ and 15 seeds of the respective native species were sowed on each pot. This resulted in a total of 150 seeds of each species on each soil type ( 15 seeds $\times 10$ pots $=150$ seed per soil type $)$. Pots containing the different soil types were arranged within the greenhouse (temperature $25-28{ }^{\circ} \mathrm{C}$, relative humidity $40 \%$ ) by following a complete random design. All pots were watered every three days with 30 $\mathrm{ml}$ of distilled water. Since most seeds in the pots were superficially buried, it was hard to assess the emergence of the radicle. Thus, we assumed that seed germination had successfully occurred when the aerial shoots of seedlings were observed. Seedling emergence was monitored every three days during 60 days.

Besides testing whether soils collected beneath peppertrees affect germination, the seedlings resulting from the greenhouse experiments were used to assess whether peppertrees affect the growth of succulent plants. For this, the seedlings were removed from the pots at the end of the experiment, taking care of avoiding damage on their aerial shoots and radicular systems. Recovered seedlings were separately stored in paper bags and dried at $60{ }^{\circ} \mathrm{C}$ in an air-forced stove until they were completely desiccated. Each seedling was weighed in an analytical balance (accuracy $0.00001 \mathrm{~g}$ ) to assess its dry biomass. Since several seedlings were recovered from each experimental pot, dry biomass was averaged across seedlings belonging to the same pot to avoid pseudoreplication in the statistical analyses described below (Hurlbert, 1984).

Statistical analyses. Failure-time-analyses were used to compare germination rates among treatments of the in vitro germination bioassays. These analyses were conducted separately for each native species and, in all cases, the Kaplan-Meier's method (Kaplan and Meier, 1958) was used to estimate germination rates at each watering treatment. The Gehan's generalized Wilcoxon $\chi^{2}$ test (Lee, 1980) was used to assess differences in germination rates among treatments. When differences were detected, the Cox-Mantel two-sample test (Lee et al., 1975) was used to perform pairwise comparisons between treatments. In these analyses, the germination of a single seed in a given monitoring date is recorded as a "failure event" (Aalen et al., 2008) and, thus, each seed is considered as a replicate ( $\mathrm{n}=100$ per watering treatment). In the greenhouse experiments, failuretime-analyses were also used to compare seedling emergence rates of native species among soil types but, in this case, each aerial shoot was considered as a replicate $(n=150$ per soil type).

The dry biomass of seedlings obtained in the greenhouse experiments was firstly compared among soil types with one-way ANOVA. These analyses were conducted separately for each native species and, when differences were detected, the post-hoc Tukey test was used to assess differences between soil types. In these analyses, the experimental pots assigned to each soil type were considered as replicates $(n=10$ per soil type).

\section{Results}

Allelopathic potential of peppertrees. Germination rates of all native species significantly differed among watering treatments in the in vitro bioassays (results of statistical analyses in Table 1). Pairwise comparisons between seeds watered with peppertree extracts and control seeds indicated that this invasive species contains secondary metabolites that can inhibit the germination of succulent plants from the Chihuahuan Desert (Figure 1). Nevertheless, the magnitude of these effects varied among plant organs (staminate flowers, fruits and leaves of male and female peppertrees), between concentrations of the aqueous extracts (concentrated and diluted extracts) and across native species. 
Figure 1. Germination rates for the six native species used in the in vitro germination bioassays. Symbols on the side of each figure indicate the watering treatment to which each curve belongs to. Different letters accompanying the symbols indicate statistical differences in germination rates between treatments (Cox-Mantel test critical $\alpha=0.05$ in all cases).

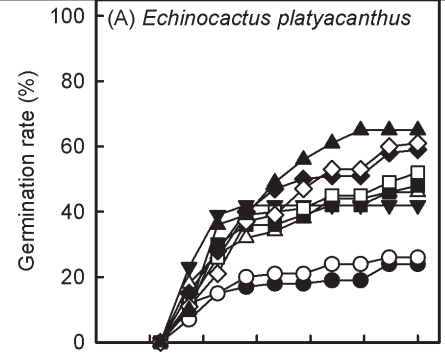

- Staminate flowers (concentrated)

a $O$ Staminate flowers (diluted)

b $\boldsymbol{\nabla}$ Fruits (concentrated)

b $\Delta$ Fruits (diluted)

- Male leaves (concentrated)

$\square$ Male leaves (diluted)

- Female leaves (concentrated)

$\diamond$ Female leaves (diluted)

$\Delta$ Control group

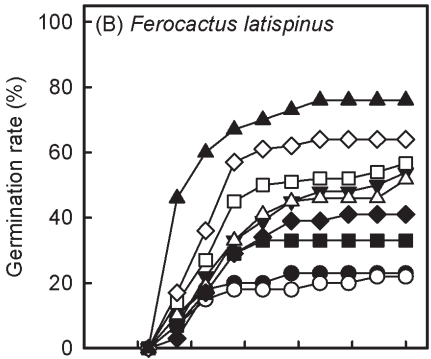

- Staminate flowers (concentrated)

O Staminate flowers (diluted)

$\boldsymbol{\nabla}$ Fruits (concentrated)

$\Delta$ Fruits (diluted)

c Male leaves (concentrated)

b $\square$ Male leaves (diluted)

bc Female leaves (concentrated)

$\mathrm{d} \diamond$ Female leaves (diluted)

e $\Delta$ Control group

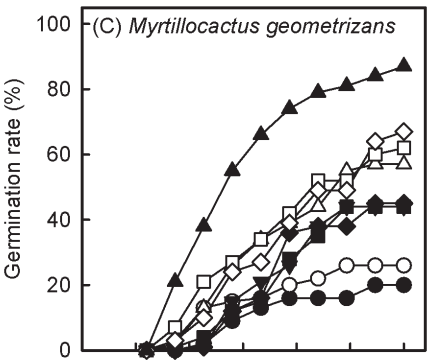

a Staminate flowers (concentrated)

O Staminate flowers (diluted)

$\nabla$ Fruits (concentrated)

$\triangle$ Fruits (diluted)

- Male leaves (concentrated)

․ Male leaves (diluted)

- Female leaves (concentrated)

$\diamond$ Female leaves (diluted)

$\Delta$ Control group

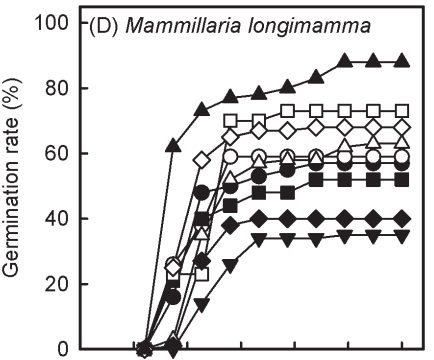

- Staminate flowers (concentrated)

O Staminate flowers (diluted)

b Fruits (concentrated)

ac $\Delta$ Fruits (diluted)

a Male leaves (concentrated)

c $\square$ Male leaves (diluted)

- Female leaves (concentrated)

$\diamond$ Female leaves (diluted)

$\Delta$ Control group

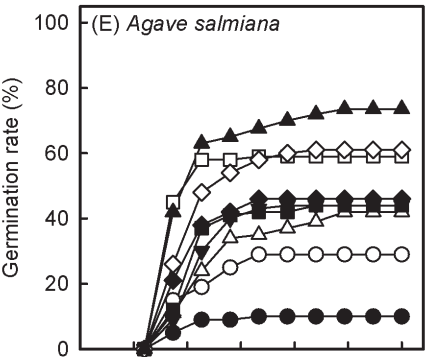

- Staminate flowers (concentrated)

Staminate flowers (diluted)

$\nabla$ Fruits (concentrated)

$\triangle$ Fruits (diluted)

- Male leaves (concentrated)

$\square \quad$ Male leaves (diluted)

- Female leaves (concentrated)

$\diamond \quad$ Female leaves (diluted)

- Control group

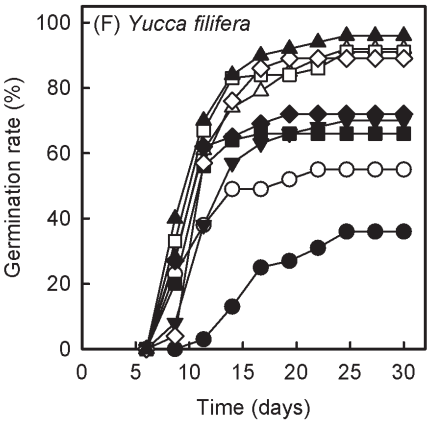

Staminate flowers (concentrated)

Staminate flowers (diluted)

$\nabla$ Fruits (concentrated)

$\triangle$ Fruits (diluted)

- Male leaves (concentrated)

$\square \quad$ Male leaves (diluted)

Female leaves (concentrated)

$\diamond$ Female leaves (diluted)

A Control group 
Table 1. Results of statistical analyses conducted to assess the allelopathic effects of Peruvian peppertrees on Mexican native species. These analyses were conducted separately for each succulent species (critical $\alpha=0.05$ in all cases). The table shows the results of the Gehan's generalized Wilcoxon $\chi^{2}$ tests comparing germination rates among watering treatments of the in vitro germination bioassays and shoot emergence rates among soil types in the greenhouse experiments. The last column of the table shows the results of the one-way ANOVA used to compare seedling dry biomass among soil types used in the greenhouse experiments.

\begin{tabular}{llll} 
Target species & $\begin{array}{l}\text { Germination rates of the in vitro } \\
\text { germination bioassays }\end{array}$ & $\begin{array}{l}\text { Shoot emergence rates in the } \\
\text { greenhouse experiments }\end{array}$ & $\begin{array}{l}\text { Dry biomass of seedlings in the } \\
\text { greenhouse experiments }\end{array}$ \\
\hline $\begin{array}{lll}\text { Echinocactus platyacanthus } \\
\text { Ferocactus latispinus }\end{array}$ & $\begin{array}{l}\chi_{(8)}^{2}=44.629 ; p<0.001 \\
\chi_{(8)}^{2}=108.896 ; p<0.001\end{array}$ & $\begin{array}{l}\chi_{(2)}^{2}=28.634 ; p<0.001 \\
\chi_{(2)}^{2}=27.895 ; p<0.001\end{array}$ & $\begin{array}{l}F_{(2,27)}=783.667 ; p<0.001 \\
\text { Mammillaria longimamma }\end{array}$ \\
$\begin{array}{ll}\text { Myrtillocactus geometrizans } \\
\text { Agave salmiana }\end{array}$ & $\chi_{(8)}^{2}=188.694 ; p<0.001$ & $\chi_{(2)}^{2}=58.535 ; p<0.001$ & $F_{(2,27)}=1384.189 ; p<0.001$ \\
Yucca filifera & $\chi_{(8)}^{2}=175.039 ; p<0.001$ & $\chi_{(2)}^{2}=25.355 ; p<0.001$ & $F_{(2,27)}=552.7855 ; p<0.001$ \\
& $\chi_{(8)}^{2}=117.895 ; p<0.001$ & $\chi_{(2)}^{2}=38.930 ; p<0.001$ & $F_{(2,27)}=403.324 ; p<0.001$ \\
& $\chi_{(8)}^{2}=202.539 ; p<0.001$ & $\chi_{(2)}^{2}=9.216 ; p=0.009$ & $F_{(2,27)}=205.734 ; p<0.001$ \\
\hline
\end{tabular}

Germination rates of Echinocactus platyacanthus were only reduced by extracts of staminate flowers, and these inhibitory effects occurred irrespectively of the concentration of the aqueous extracts (Figure 1A). In this case, no differences were found among the other treatments, including the control (Figure 1A). In Ferocactus latispinus (Figure 1B) and Myrtillocactus geometrizans (Figure 1C), the concentrated and diluted extracts of staminate flowers also reduced germination rates in higher magnitudes than the other treatments. Nevertheless, for these two cacti, extracts obtained from all other peppertree organs also led to lower germination rates than those estimated for control seeds (Figure 1). Conversely to that reported for these cactus species, germination rates of Mammillaria longimamma were more strongly reduced by the concentrated extracts of fruits and leaves of female peppertrees (Figure 1D). Nevertheless, the germination of this species was also inhibited by the other peppertree extracts, as compared to control seeds (Figure 1D).

The two succulent monocots, Agave salmiana (Figure 1E) and Yucca filifera (Figure 1F), displayed lower germination rates when watered with the concentrated extract of staminate flowers, as compared to all the other watering treatments. The diluted extract of staminate flowers also caused lower germination rates in these two species than the other watering treatments (Figure $1 \mathrm{E}$ and $1 \mathrm{~F}$ ). In the case of A. salmiana, inhibitory effects were also observed for the concentrated and diluted extracts of fruits and leaves of both peppertree genders (Figure 1E). Nevertheless, the diluted extracts of these plant organs did not affect germination rates of $Y$. filifera, as compared to control seeds (Figure 1F).

Allelopathy in soils beneath peppertrees. Shoot emergence rates and seedling biomass of all succulent species significantly differed among soil types (results of statistical analyses in Table 1). However, the magnitude with which soil types affected these response variables varied among species.

Shoot emergence rates of Echinocactus platyacanthus (Figure 2A), Ferocactus latispinus (Figure 2B) and Myrtillocactus geometrizans (Figure 2C) were lower in the soil collected beneath male peppertrees, as compared to the other soil types. Nevertheless, these three species also displayed lower shoot emergence rates in the soil collected beneath female peppertrees than in the control soil collected in open areas without vegetation cover (Figure 2A, 2B and 2C). On the other hand, shoot emergence rates of Mammillaria longimamma did not differ between soils collected beneath male and female peppertrees, but these two soil types reduced shoot emergence rates as compared with the control soil (Figure 2D). The two succulent monocots, Agave salmiana (Figure 2D) and Yucca filifera (Figure 2F), displayed lower shoot emergence rates in soils collected beneath male peppertrees. Nevertheless, while shoot emergence rates of A. salmiana were also reduced on soil collected beneath female peppertrees (Figure 2D), shoot emergence rates of $Y$. filifera on this soil type did not differ from those estimated for the control soil (Figure 2F).

Seedlings of Echinocactus platyacanthus (Figure 3A) and Ferocactus latispinus (Figure 3B) 

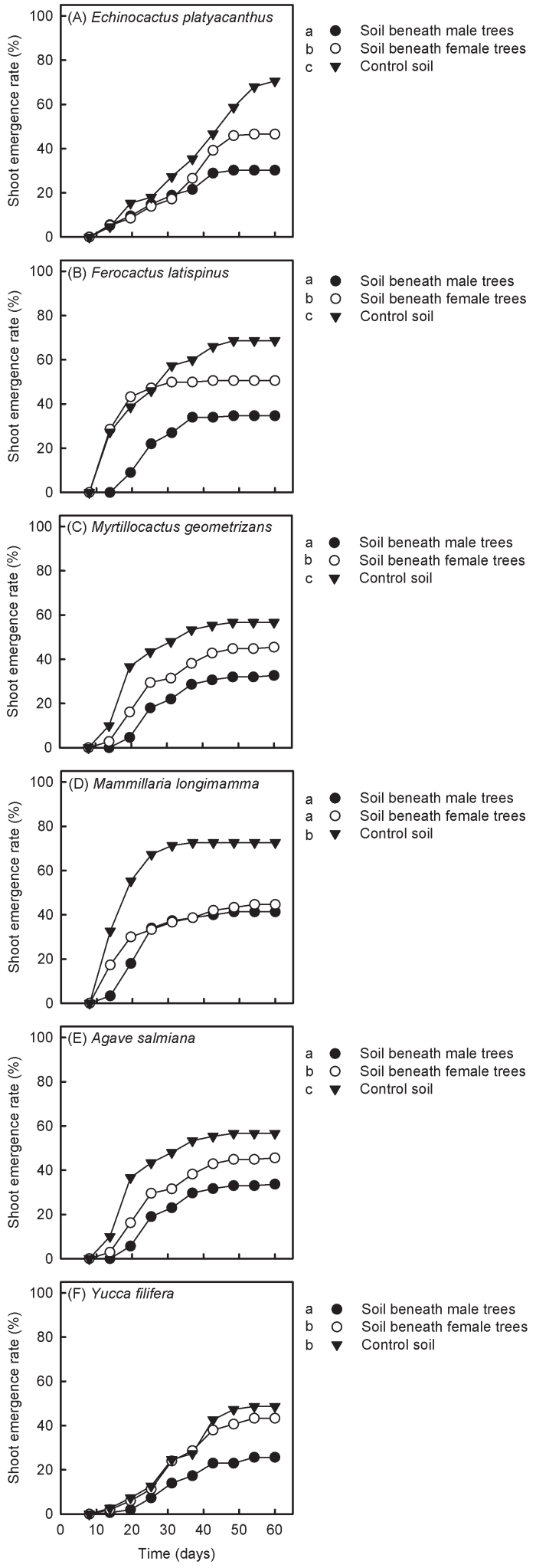

Figure 2. Shoot emergence rates estimated for the six native species used in the greenhouse experiments. Symbols on the side of each figure indicate the watering treatment to which each curve belongs to. Different letters accompanying the symbols indicate statistical differences in shoot emergence rates between treatments (Cox-Mantel test critical $\alpha=0.05$ in all cases). showed lower biomass in soils collected beneath both peppertrees genders than in the control soil. Nevertheless, in both cases, soil collected beneath male peppertrees had stronger negative effects than soil collected beneath female trees (Figure 3A and 3B). Myrtillocactus geometrizans and Mammillaria longimamma also displayed lower seedling biomass on soils collected beneath the canopy of this invasive species, but no differences were found between peppertree genders (Figure 3C and 3D). Biomass of Agave salmiana seedlings was lower on soils collected beneath peppertrees than in the control soil, but seedlings grown on soil collected beneath male individuals were smaller than those grown on soil collected beneath female trees (Figure 3E). The biomass of seedlings of Yucca filifera, on the other hand, was negatively affected by the soil collected beneath male peppertrees, while no differences were found between seedlings grown on the soil collected beneath female trees and the control soil (Figure 3F).

\section{Discussion}

The in vitro germination bioassays clearly indicated that Peruvian peppertrees contain secondary metabolites that negatively affect the germination of succulent plants from the Chihuahuan desert. These bioassays also indicated that the magnitude of these effects might vary between vegetative and reproductive plant organs, as well as between male and female peppertrees. Although it is important to recognize that these differential effects may be partially due to the influence of chemical variables that we were unable to measure, such as the osmotic potentials of the aqueous extracts, our results suggest that staminate flowers produced by male individuals would have the most remarkable inhibitory effects on the germination of these species. To our best knowledge, this is the first study reporting such differential allelopathic effects between genders of a dioecious species and, in the particular case of the peppertrees, male individuals seem to have higher potential than female individuals for inhibiting the germination of succulent plants.

Yang et al. (2012) have previously shown that the accumulation of secondary metabolites in living tissues depends on the plant organ in which they are synthesized. This differential production and accumulation of secondary metabolites might explain why the inhibitory effects of staminate flowers were stronger than those other plant organs, including the fruits produced by female trees. Nevertheless, it is important to highlight that the cactus Mammillaria longimamma displayed lower germination rates in those watering treatments where extracts from fruits and leaves of female trees were applied. This differential response of $M$. longimamma, as compared to the other native species, suggests succulent plants from the Chihuahuan desert may be differentially sensitive to different secondary metabolites produced by male and female peppertrees. Nevertheless, detailed biochemical analyses are still being required to determine whether the concentration and nature of secondary metabolites vary among plant organs, as well as between genders of the Peruvian peppertrees. 
Figure 3. Dry biomass of seedlings (average \pm 2 S.E.) of the six native species grown on the different soil types used in the greenhouse experiments. Different letters indicate statistical differences between soil types (Tukey test critical $\alpha=0.05$ in all cases).
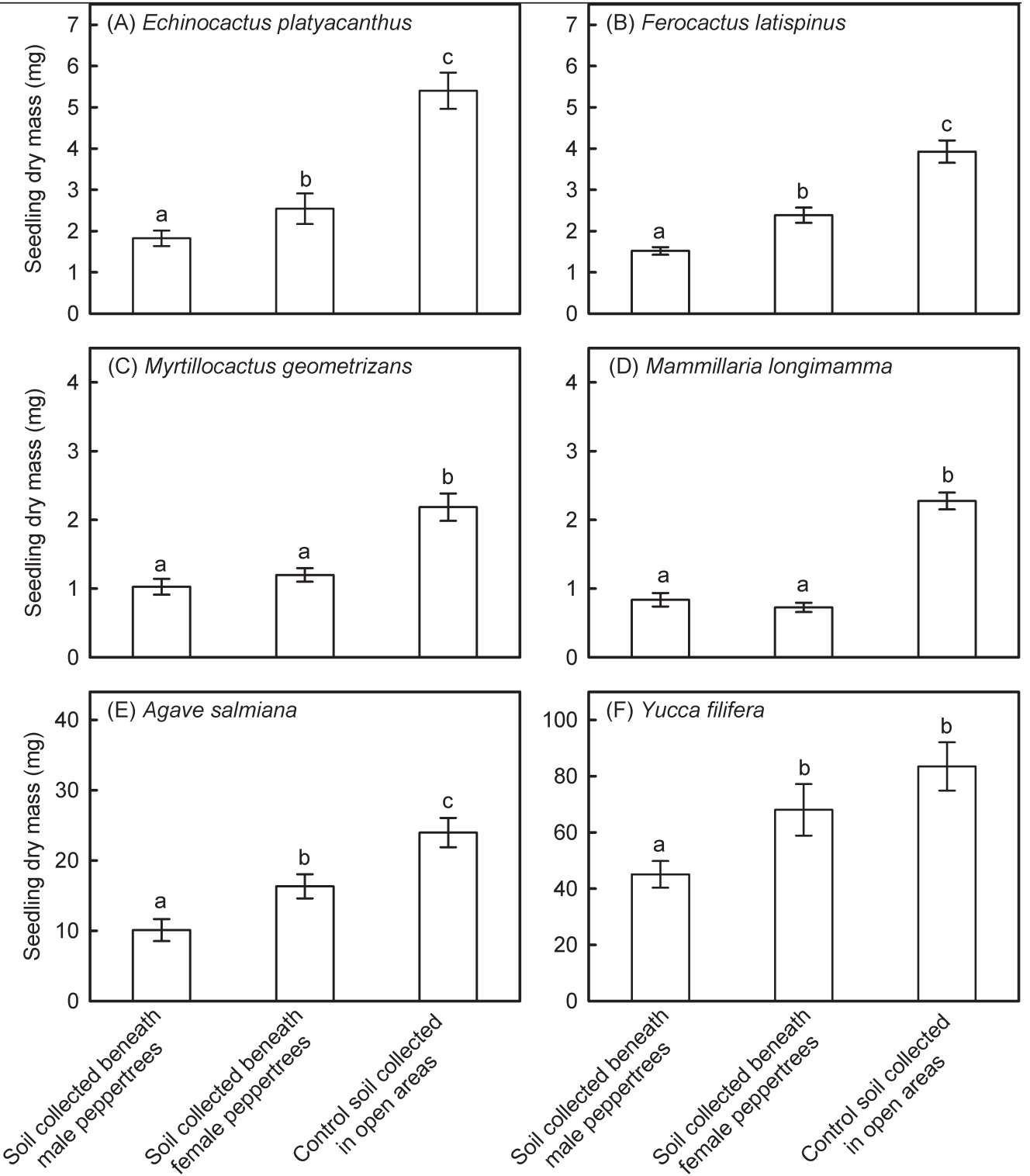

The greenhouse experiments complemented the results of the in vitro bioassays, showing that soil collected beneath both peppertree genders also inhibit the germination of native species. Here, it is important to recognize that these results may be influenced by differences in the concentration of nutrients among soil types, which were not measured in this study. Nevertheless, the strong reduction of germination observed on soils collected beneath peppertrees, as well as the elevated concurrence of results between this experiment and the in vitro bioassays, allow suggesting that the secondary metabolites produced by this invasive tree are released to the environment and accumulated in the soil beneath their canopies. Additionally, these experiments indicated that male and female individuals may also have differential allelopathic effects on native species in the field. On this issue, five of the six species used in these experiments displayed lower shoot emergence rates on soils collected beneath male peppertrees. The only exception was Mammillaria longimamma, whose germination rates were similarly inhibited by soils collected beneath both tree genders. These results then suggest that male peppertrees would be more aggressive than female individuals for inhibiting the establishment of succulent plants that are colonizing abandoned agricultural fields of Mexico.

Soils collected beneath peppertrees also affected seedling biomass, as compared to control soils collected in open areas without vegetation cover. In this case, the seedlings of two cacti 
(Echinocactus platyacanthus and Ferocactus latispinus) and the two succulent monocots (Agave salmiana and Yucca filifera) displayed lower biomass on soils collected beneath male peppertrees than in the other soil types. This reinforces the suggestion that male peppertrees trees have higher potential than female individuals to impair the performance of these succulent species. Nevertheless, seedling biomass of Myrtillocactus geometrizans and Mammillaria longimamma was similarly reduced on soils of both tree genders, hence suggesting that female trees can also prevent the development of some native species.

Irrespective of these differential allelopathic effects of male and female peppertrees, it is important to highlight that this invasive species may be threatening the recovery of native plant communities in abandoned agricultural fields. On this issue, our results might fit to the "novel weapons hypothesis" (Callaway and Ridenour, 2004). This hypothesis attempts to explain why those plants that have no inhibitory effects on other species in their native distribution ranges become strongly allelopathic in the new geographic areas they invade. The novel weapons hypothesis then proposes that this occurs because native plants of invaded sites have never been exposed to the secondary metabolites of their new neighbors and, thus, they lack adaptations to face the biochemical arsenal of the invaders (Callaway and Aschehoug, 2000; Ridenour and Callaway, 2001; Bais et al., 2003; Hierro and Callaway, 2003). As far as we are aware, the Peruvian peppertree has not been reported to affect germination of South American plant species, but this study clearly suggests that Mexican succulent plants are sensitive to the secondary metabolites produced by this invasive species. Thus, although more research is needed to assess the magnitude of these effects in the field, our results allow proposing that urgent actions are required to control the spread of peppertrees in Mexico and hence promote the recovery of native vegetation in human-disturbed areas of semiarid regions.

\section{Acknowledgements}

This study was supported by Secretaría de Educación Pública-Consejo Nacional de Ciencia y Tecnología, project CB-2010-156205 to JFR. The authors thank N. Prieto her valuable revision of the orthography, grammar and style of the English version of this manuscript.

\section{Literature cited}

Aalen O., Borgan Ø. and Gjessing H.K. 2008. Survival and event history analysis: a process point of view. Springer, New York.

Alston K.P. and Richardson D.M. 2006. The roles of habitat features, disturbance, and distance from putative source populations in structuring alien plant invasions at the urban/wildland interface on the Cape Peninsula, South Africa. Biological Conservation 132:183-198.

Anaya A.L. and Gómez-Pompa A. 1971. Inhibición del crecimiento producida por el "piru" (Schinus molle L.). Revista de la Sociedad Mexicana de Historia Natural 32:99-110.

Arredondo-Gómez A. and Sotomayor M. del C. J.M. 2009. Cactáceas en categoría de riesgo en el estado de San Luis Potosí. Publicación especial No. 1, Instituto Nacional de Investigaciones Forestales, Agrícolas y Pecuarias, San Luis Potosí.

Badano E.I. and Pugnaire F.I. 2004. Invasion of Agave species (Agavaceae) in south-east Spain: invader demographic parameters and impacts on native species. Diversity and Distributions 10:493-500.

Bais H.P., Vepachedu R., Gilroy S., Callaway R.M. and Vivanco J.M. 2003. Allelopathy and exotic plant invasion: from molecules and genes to species interactions. Science 301:1377-1380.

Bakker J. and Wilson S. 2001. Competitive abilities of introduced and native grasses. Plant Ecology 157:119-127.

Barroso M.S.T., Villanueva G., Lucas A.M., Perez G.P., Vargas R.M.F., Brun G.W. and Cassel E. 2011. Supercritical fluid extraction of volatile and non-volatile compounds from Schinus molle L. Brazilian Journal of Chemical Engineering 28:305-312.

Batish D.R., Singh H.P., Kohli R.K., Saxena D.B. and Kaur S. 2002. Allelopathic effects of parthenin against two weedy species Avena fatua and Bidens pilosa. Environmental and Experimental Botany 47:149-155.

Blancas J., Casas A., Rangel-Landa S., Moreno-Calles A., Torres I., Pérez-Negrón E., Solís L., DelgadoLemus A., Parra F., Arellanes Y., Caballero J., Cortés L., Lira R. and Dávila P. 2010. Plant Management in the Tehuacán-Cuicatlán Valley, Mexico. Economic Botany 64:287-302. 
Received:

Jamuary 19th, 2015

Accepted:

May 7th, 2015
Borella J., Martinazzo E.G. and Aumonde T.Z. 2011 Atividade alelopática de extratos de folhas de Schinus molle L. sobre a germinação eo crescimento inicial do rabanete. Revista Brasileira de Biociências 9:398-404.

Bye R.A. and Linares E. 1983. The role of plants found in the Mexican markets and their importance in ethnobotanical studies. Journal of Ethnobiology 3:1-13.

Callaway R.M. and Aschehoug E.T. 2000. Invasive plants versus their new and old neighbors: a mechanism for exotic invasion. Science 290:521-523.

Callaway R.M. and Ridenour W.M. 2004. Novel weapons: invasive success and the evolution of increased competitive ability. Frontiers in Ecology and the Environment 2:436-443.

Castro S.A., Badano E., Guzman D. and Cavieres L. 2010. Biological invasion of a refuge habitat: Anthriscus caucalis (Apiaceae) decreases diversity, evenness, and survival of native herbs in the Chilean matorral. Biological Invasions 12:1295-1303.

Didham R.K., Tylianakis J.M., Hutchison M.A., Ewers R.M. and Gemmell N.J. 2005. Are invasive species the drivers of ecological change? Trends in Ecology and Evolution 20:470-474.

Eliason S.A. and Allen E.B. 1997. Exotic grass competition in suppressing native shrubland re-establishment. Restoration Ecology 5:245-255.

Hierro J.L. and Callaway R.M. 2003. Allelopathy and exotic plant invasion. Plant and Soil 256:29-39.

Hurlbert S.H. 1984. Pseudoreplication and the design of ecological field experiments. Ecological Monographs 54:187-211.

Inderjit, Seastedt T.R., Callaway R.M., Pollock J.L. and Kaur J. 2008. Allelopathy and plant invasions: traditional, congeneric, and bio-geographical approaches. Biological Invasions 10:875-890

Kaplan E.L. and Meier P. 1958. Nonparametric estimation from incomplete observations. Journal of the American Statistical Association 53:457-481.

Kramer F.L. 1957. The pepper tree, Schinus molle L. Economic Botany 11: 322-326.

Lee E.T. 1980. Statistical methods for survival data analysis. Lifetime Learning Publications, Belmont.

Lee E.T., Desu M.M. and Gehan E.A. 1975. A Monte Carlo study of the power of some two-sample tests. Biometrika 62:425-432.

Levine J.M., Kennedy T. and Naeem S. 2002. Neighborhood scale effects of species diversity on biological invasions and their relationship to community patterns. In: Loreau M., Naeem S. and Inchausti P. Eds. Biodiversity and ecosystem functioning. Synthesis and Perspectives, pp. 114-124, Oxford University Press, Oxford.

Lozon J.D. and MacIsaac H.J. 1997. Biological invasions: are they dependent on dis disturbance? Environmental Reviews 5:131-144.

Materechera S.A. and Hae M.E. 2008. Potential of aqueous extracts from parts of the pepper tree (Schinus molle L.) to affect emergence and seedling development of wheat (Triticum sativa $\mathrm{L}$ ) and weeds in a manure amended soil. The Open Agriculture Journal 2:99-104.

Medina-García G., Díaz-Padilla G., Loredo-Osti C., Serrano-Altamirano V., and Cano-García M.G. 2005. Estadísticas climatológicas básicas del estado de San Luis Potosí (1961-2001). Libro Técnico No.2, Instituto Nacional de Investigaciones Forestales Agrícolas y Pecuarias, Mexico D.F.

Muller C.H. 1969. Allelopathy as a factor in ecological process. Vegetatio 18:348-357.

Paredes-Flores M., Lira-Saade R. and Dávila-Aranda P.D. 2007. Estudio etnobotánico de Zapotitlán Salinas, Puebla. Acta Botánica Mexicana 79:13-61.

Ramírez-Albores J.E. and Badano E.I. 2013. Perspectiva histórica, sociocultural y ecológica de una invasión biológica: el caso del Pirúl (Schinus molle L., Anacardiaceae) en México. Boletín de la Red Latinoamericana para el Estudio de Especies Invasoras 3:4-15.

Ridenour W.M. and Callaway R.M. 2001. The relative importance of allelopathy in interference: the effects of an invasive weed on a native bunchgrass. Oecologia 126:444-450.

Yang C.-Q., Fang X., Wu X.-M., Mao Y.-B., Wang L.-J. and Chen X.-Y. 2012. Transcriptional regulation of plant secondary metabolism. Journal of Integrative Plant Biology 54:703-712.

Zahed N., Hosni K., Brahim N.B., Kallel M. and Sebei H. 2010. Allelopathic effect of Schinus molle essential oils on wheat germination. Acta Physiologiae Plantarum 32:1221-1227.

Zhang C. and Fu S. 2009. Allelopathic effects of eucalyptus and the establishment of mixed stands of eucalyptus and native species. Forest Ecology and Management 258:1391-1396. 